\title{
Р.К. КАРАКУЛОВ
}

${ }^{1}$ АО Казахский НИИ онкологии и радиологии, Алматы, Республика Казахстан

\section{История развития онкогематологии в Казахском НИИ онкологии и радиологии}

\begin{abstract}
Статья посвящена истории создания и развития отделения онкогематологии в Казахском НИИ онкологии и радиологии. Впервые авторами статьи приведены сведения о развитии онкогематологии в Казахском НИИ онкологии и радиологии в эпоху СССР и Казахской ССР, позже - в независимом Казахстане. Также рассказывается о роли директоров института и вкладе руководителей отделения на разных этапах его истории. Приведены сведения о том, на каком этапе развития отделения были внедрены новые современные методы диагностики злокачественных лимфом и новые технологии лечения гемобластозов. Кроме того, авторы статьи указывают на актуальные проблемы онкогематологии и пути их решения.
\end{abstract}

Ключевые слова: становление гематологической службы, вредные антропогенные факторы.

Здравоохранение отнесено к национальным приоритетам современного социально-экономического развития Казахстана как суверенного государства. В Государственной программе реформирования и развития здравоохранения в числе приоритетных задач обозначены системный переход на международные стандарты, новые технологии, современные методики лечения и медицинского обслуживания, а также профилактика, диагностика и лечение социально значимых заболеваний. В этой связи актуальными вопросами на сегодняшний день являются проблемы онкогематологии.

Становление и развитие гематологической службы в Республике Казахстан пришлось на середину 1960-х годов, когда впервые в СССР были открыты гематологические стационары и начата подготовка специалистов. Необходимость этого была продиктована постепенным ростом заболеваемости злокачественными новообразованиями (3Н), в том числе гематологическими заболеваниями. Первые гематологические отделения в Казахстане были открыты в 1963 году в двух городах - в Алма-Ате (на базе 7й ГКБ в посёлке Калкаман) на 60 коек и в Караганде на 40 коек. В 70-е годы число гематологических коек в Казахстане для взрослых пациентов увеличилось до 129.

В связи с усилением влияния вредных антропогенных факторов на организм человека (последствия деятельности СИЯП, авария на Чернобыльской АЭС, добыча урана в Степногорске открытым способом, работа Усть-Каменогорского цинково-свинцового комбината и т.д.), число больных гематологическими заболеваниями в Казахстане увеличилось.

В 1983 г. по приказу Министра здравоохранения СССР были созданы гематологические отделения в различных регионах СССР, в том числе Гематологический центр на базе Центрального Ордена Ленина института переливания крови (ЦОЛИПК) в г. Москве. Летом 1983 года на основании приказа Министра здравоохранения СССР и соответствующего приказа Министра здравоохранения Казахской ССР было организовано отделение лимфогранулематоза (ЛГМ) на базе Казахского НИИ онкологии и радиологии на 20 коек. В тот период директором института был профессор Одак Кабиевич
Кабиев, который внёс огромный вклад в организацию и развитие этого отделения.

С 1983 г по 1988г отделением руководила великолепный специалист-гематолог, кандидат медицинских наук Шакар Жартовна Балгожина, которая закончила аспирантуру в Гематологическом центре в г. Москве и защитила диссертацию под руководством академика Иосифа Абрамовича Кассирского. Впоследствии Ш.Ж. Балгожина подготовила и воспитала несколько поколений гематологов.

В отделении в основном получали лечение пациенты с ЛГМ, лимфосаркомой (неходжкинские лимфомы, НХЛ), миеломной болезнью, реже - хроническими лимфо- и миелолейкозами. В тот период отделение считалось Республиканским центром по диагностике и лечению злокачественных лимфом и оказывало помощь всем жителям Республики Казахстан.

Лечение проводили только на основании данных цитологического исследования костного мозга и гистологического исследования биоптата. Шакар Жартовна сама производила пункции костного мозга, расшифровывала миелограммы и ставила диагноз.

В 1989 г. директор КазНИИОиР проф. А.А. Бейсебаев объединил отделение ЛГМ с отделением химиотерапии опухолей, которым руководил химиотерапевт проф. Борис Васильевич Монахов. При лечении пациентов с 3Н акцент делался на проведении полихимиотерапии. Основным методом терапии пациентов с 3 Н в отделении оставалось комбинированное лечение. Лекарственная терапия проводилась по схемам СОРР, СVPР и АСОР, которые включали такие препараты, как циклофосфамид, винкристин, винбластин, метотрексат, натулан, 6-МП, адриабластин, преднизолон и т.д.

Позже, лучевая терапия стала доминирующим методом при лечении пациентов с ЛГМ. С запуском линейных ускорителей лУЭВ 15M1 и Clinac 2100, в клиническую практику были широко внедрены методы лечения быстрыми электронами - лучевой терапии по радикальной программе выше и ниже диафрагмы до СОД 40-42 Гр. При применении такой терапии пятилетняя безрецидивная выживаемость пациентов (БВ) с ЛГМ стадий I-II А и В достигала 85,0-90,0\%. Автор этой программы - проф. 
Г.Д. Байсоголов из НИИМР (г. Обнинск) МЗ РФ - был удостоен Ленинской премии.

Название отделения ЛГМ менялось с приходом каждого нового руководителя института. В 1991 г. директором института был назначен член-корреспондент АН КазССР, профессор Ж.Н. Абдрахманов. Он переименовал отделение ЛГМ в Отделение лучевой терапии лимфом, соответственно его профилю.

С 1991 по 1995 гг. отделением руководил радиолог, д.м.Н., профессор Н.А. Ажигалиев. Будучи специалистом по радиологии, он делал основной акцент в лечении лимфом на лучевую терапию. Кроме пациентов с лимфомой, в отделении стали принимать больных с другими солидными опухолями для проведения лучевой терапии.

С 1998 по 2006 годы отделением руководил доктор медицинских наук, профессор Р.К. Каракулов, который стоял у истоков создания этого отделения. Проф. Каракулов всегда отстаивал статус отделения в Министерстве здравоохранения КазССР. В тот период в отделении функционировало 30 коек. Лечение получали пациенты в основном с НХЛ, лимфомой Ходжкина (ХЛ), множественной миеломой (ММ), ХМЛ, ХЛЛ и другими локализациями. Были внедрены новые методы диагностики: метод ИГХ-исследования при лимфомах, изучение пролиферативного пула опухоли для проведения персонифицированного лечения. Кроме того, были внедрены новые технологии в лечении пациентов с рефрактерной формой лимфом, а именно применение радиомодификатора интратуморальное введение метронидазола с последующей лучевой терапией. Проведение лучевой терапии на фоне применения иммуномодуляторов (индукторов интерферона) позволило на 40\% снизить постлучевые осложнения у больных, в частности явления постлучевого пульмонита. Впервые в Казахстане при рефрактерных формах НХЛ и ХЛ были использованы моноклональные антитела (ритуксимаб, брентуксимаб и т.д.)

Впервые в своей истории отделение имело свое научное направление: «Применение радиомодификаторов и иммуномодуляторов при лучевой терапии злокачественных лимфом». Сотрудники отделения получили 10 патентов на изобретения, дважды выигрывали Гранты МОН РК и один раз - Грант НАН РК. По этому направлению были защищены кандидатские и докторские диссертации. В качестве зав. Отделением, проф. Каракулов подготовил 5 кандидатов медицинских наук и двух докторов наук.

Отделение является учебной базой для бакалавров КазНМУ, интернов и резидентов КазНИИОиР и КазНМУ. За последние 5 лет отделение подготовило 9 резидентов-гематологов для регионов РК. Два сотрудника обучаются в докторантуре в КазНИИОиР и Казахском национальном университете им Аль-Фараби. Сотрудники отделения принимают активное участие в ежегодных конгрессах Европейской гематологической ассоциации (ЕНA), а также в ежегодном Евразийском гематологическом конгрессе в Турции. Сотрудники прошли повышение квалификации в Институте детской онкологии, гематологии и трансплантологии им. Р.М. Горбачевой (г. Санкт-Петербург) по сепарации стволовых клеток и аутотрансплантации ГСК.

Проф. Каракулов опубликовал более 350 научных работ, из них 53 - за рубежом, 2 монографии, 1 книгу, 1 методическую рекомендацию. В течение 10 лет он возглавлял
ППО Nur Otan в КазНИИОиР, которая трижды занимала первое место по Алмалинскому району и второе - по городскому филиалу Nur Otan. Неоднократно награждался грамотами Первого Президента РК Н.А. Назарбаева и Президента РК К-Ж.К. Токаева и является обладателем медали «Отличник здравоохранения СССР», «Юбилейной медали» и значка «Изобретатель СССР».

В 2009-2010 годах отделением руководила врач-гематолог, к.м.н. С.Е. Султангазиева. При ней отделение сохранило свое название - Отделение гемобластозов. В отделении функционировали 30 коек, лечение получали пациенты с лимфомой и лейкозами, в основном в хронической форме. Светлана Елеусизовна впервые начала внедрять методы цито- и молекулярно-генетического изучения при лимфомах, хронических лейкозах. Исследования проводились на базе НИИ акушерства и гинекологии МЗ РК по договору.

С 2011 года по сей день отделением руководит врач-гематолог высшей категории, PhD, Сауле Телембаевна Габбасова. С ее приходом в отделении произошли позитивные перемены. Практически все сотрудники отделения прошли обучение в Институте детской онкологии, гематологии и трансплантологии им. Р.М. Горбачевой. Ими были освоены новые современные методы диагностики лейкозов, как цитогенетические исследования костного мозга, FISH-исследование биопсионного и костного мозга. Впервые был использован метод высокодозной ПХТ при рефрактерных формах лимфом, лейкозов и ММ. С 2014 года в практику отделения внедрен метод аутотрансплантации ГСК, за 6 лет проведено более 40 аутотрансплантаций ГСК пациентам с гемобластозами. Внедрение данного метода позволило улучшить БВ и качество жизни пациентов. С 2018 г. в рамках Грантового исследования в отделении проводится изучение профиля экспрессии генов для идентификации молекулярных подгрупп неходжкинских В-клеточных лимфом для проведения персонифицированной терапии. Следует отметить, что все эти позитивные изменения в отделении происходили благодаря поддержке нынешного директора института, д.м.н., академика Кайдаровой Д.Р. В связи с увеличением числа пациентов, поступающих в отделение, в КазНИИОиР был создан Центр гематологии и трансплантации костного мозга на 45 коек.

С 2019 г. отделение онкогематологии переименовано в Центр гемобластозов и трансплантации костного мозга. Пациенты поступают со всех регионов Казахстана, им оказывается высокоспециализированная помощь (высокодозная ПХТ и аутотрансплантация ГСК при лимфомах, лейкозах и множественной миеломе). Кроме того, используются новое поколение моноклональных антител при лимфомах и множественной миеломе.

Учитывая постоянный рост числа больных гемобластозами в PK, особенно в южных и западных регионах Республики, и неполное обеспечение санитарно-эпидемиологическими мерами для предупреждения посттрансплантационных осложнений, было бы целесообразным создать отдельный институт гематологического профиля для развития и широкого применения современных методов ауто- и аллогенной трансплантации и иммунополихимиотерапии для пациентов из западных и южных регионов Республики Казахстан. 
Список работ, опубликованных за последние 3 года Центром гемобластозов и трансплантации костного мозга КазНИИОиР:

1. Karakulov R.K., Gabbasova S.T., Karazhanova M.K., Nasipov B.A., Mirzaeva M.V. Immune polychemotherapy regimen choice in B-cell non-Hodgkin lymphoma of high and low malignancy based on the identufucation of the mutational c-myc gene and bcl2 // Онкол. Радиол. Казахстана. - 2019. №3(53). - C. 38-43.

2.Қарақұлов Р.Қ., Ғаббасова С.Т. Сағындықов. Қазақстанда В-жасушалы Ходжкиндік емес лимфомалардың кіші топтарын анықтау үшін гендік профилін зерттеу жұмысының алғашқы нәтижесі» // Онкол. Радиол. Казахстана. - 2017. - №4(46). - С. 21-22.

3. Karakulov R., Amankulov Zh. Treatment stratification of non-Hodgkin large B-cell lymphoma patients based on the identification of mutational c-MYC gene // Cit. Annals Oncol. 2019. - Vol. 30 (suppl 9):ix 91-96. - ESMO Asia, Singapore, 2019.

4. Каракулов Р.К., Габбасова С.Т., Насипов Б.А., Мирзаева М.В. Прогностическое значение коэкспрессии гена C-Mус и BCL2 при B-клеточной неходжкинской лимфоме // Онкол. Радиол. Казахстана / Спецвыпуск / Сб. тезисов VII Съезда онкол. и радиол. Казахстана с междунар. уч. Нур-Султан, 17-18 октября 2019. - С. 79-80.

5. Джазылтаева А.С., Каракулов Р.К., Габбасова С.Т., Ишкинин Е.И., Сагиндыков Г.А., Насипов Б.А., Кемелбеков Н.А. Предварительные результаты применения брентуксимаба-ведотина при рецидивирующей/рефрактерной лимфоме Ходжкина // Онкол. Радиол. Казахстана / Спецвыпуск / Сб. тезисов VII Съезда онкол. и радиол. Казахстана с междунар. уч. - Нур-Султан, 17-18 октября 2019. - С.79.

6. Каракулов Р.К., Кайназарова М.А., Габбасова С.Т., Сарсенбаева С.А., Джазылтаева А.С., Сагиндыков Г.А., Насипов Б.А., Кемелбеков Н.А. Результаты лечения больных с плазмобластической лимфомой // Онкол. Радиол. Казах- стана / Спецвыпуск / Сб. тезисов VII Съезда онкол. и радиол. Казахстана с междунар. уч. - Нур-Султан, 17-18 октября 2019. - С.80.

7. Каракулов Р.К., Кайназарова М.А., Габбасова С.Т., Сарсенбаева С.А., Джазылтаева А.С., Сагиндыков Г.А., Насипов Б.А., Кемелбеков Н.А. Предварительные результаты комбинированного лечения первичных неходжкинских лимфом орбиты глаза // Онкол. Радиол. Казахстана / Спецвыпуск / Сб. тезисов VII Съезда онкол. и радиол. Казахстана с междунар. уч. - Нур-Султан, 17-18 октября 2019. - С.80.

8. Jazyltaeva A., Karakulov R., Gabbasova S., Ishkinin E., Sagindykov G., Nassipov B., Kemelbekov N., Akanov A. Result of treatment of primary lymphomas of the brain. - EHA Library. - JAZYLTAYEVA A. - 06/14/18; 216640; PB1784.

9. Мирзаева М.В. Роль молекулярно-генетических исследований при проведении персонифицированной терапии у пациентов с В-клеточной неходжкинской лимфомой // Онкол. Радиол. Казахстана / Спецвыпуск / Сб. тезисов VII Съезда онкол. и радиол. Казахстана с междунар. уч. - Нур-Султан, 17-18 октября 2019. - С.83.

10. Пат. 34664 РК. Способ лечения диффузной В-крупноклеточной лимфомы / Р.К. Каракулов, С.Т. Габбасова, Н.А. Кемелбеков, А.С. Джазылтаева, Г.А. Сагиндыков, Б.А. Насипов, М.К. Каражанова; опубл. 30.10.2020.

11. Kaidarova D.R., Karakulov R.K., Gabbasova S.T., Karazhanova M.K., Lyubko S.A. Immune polychemotherapy regimen choice in B-cell non-Hodgkin lymphoma of high and low 1 malignancy based on the identification of the mutational c-myc and BCL 2 genes // J. Genetics and Molecular Research (submitted for review on 09.10.2020)

12. Жазылтаева А.С., Каракулов Р.К., Габбасова С.Т. Новые подходы в лечении Т-клеточных лимфом на современном этапе // Вестник КазНМУ им. С.Д. Асфендиярова. - 2019. - С.10-16.

13. Акты внедрения - 3.

\section{ТҰЖЫРЫМ}

\section{Р.К. Қарақұлов ${ }^{1}$, Д.Р. Қайдарова ${ }^{1}$, С.Т. Ғаббасова ${ }^{1}$, Б.Б. Орын ${ }^{1}$}

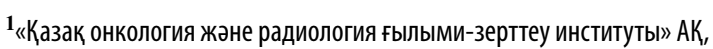
Алматы, Қазақстан Республикасы

\section{Қазақ онкология және радиология \\ ғылыми-зерттеу инстутындағы онкогематологияның даму тарихы}

Мақала Қазақ онкология және радиология ҒЗИ-ның онкогемато-
логия бөлімшесінің құрылу және даму тарихына арналған. Алғаш
рет мақала авторлары Қазақ онкология және радиология ғылыми
- зерттеу институтында КСРО мен Қазақ КСР дәуіріндегі, кейінірек
Тәуелсіз Қазақстандағы онкогематологияның даму тарихы тура-
лы ақпарат берді. Сондай-ақ, институт директорларының рөлі
мен бөлім басшыларының бөлімше тарихына әртүрлі кезеңдерде
қосқан үлесі туралы айтылады. Мақалада бөлімшенің даму ке-
зеңінде қатерлі лимфомаларды диагностикалаудың жаңа заманауи
әдістері және гемобластоздарды емдеудің жаңа технологиялары
енгізілгені туралы мәліметтер келтірілді. Сонымен қатар, мақала
авторлары онкогематологияның өзекті мәселелерін және оларды
иешужолдарын көрсетеді.
Түйін сөздер:гематологиялық қызметтің қалыптасуы, зиянды антропагенді факторлар.

\section{ABSTRACT}

\author{
R.K. Karakulov ${ }^{1}$, D.R. Kaidarova ${ }^{1}$, \\ S.T. Gabbasova ${ }^{1}$, B.B. Oryn ${ }^{1}$
}

1JSC "Kazakh Institute of Oncology and Radiology," Almaty, the Republic of Kazakhstan

\section{The history of oncohematology development at the Kazakh Institute of Oncology and Radiology}

The article is devoted to the history of creation and development of the Oncohematology Department at the Kazakh Institute of Oncology and Radiology. For the first time, the authors talk about the development of oncohematology at the Kazakh Institute of Oncology and Radiology during the Soviet period in the USSR and the Kazakh SSR, and later - in independent Kazakhstan. They also describe the role of the institute directors and the contribution of the department heads at different stages of its history and share information about introducing new modern methods of diagnosing malignant lymphomas and new technologies for treating hemoblastosis. The authors also highlight the current topical problems of oncohematology and ways to solve them.

Keywords: the establishment of hematological service, harmful anthropogenic factors. 